BIOKEMISTRI 18(2):121-125 (December 2006)

Available online at http://www.bioline.org.br/bk and at http://www.ajol.info/journals/biokem

Printed in Nigeria

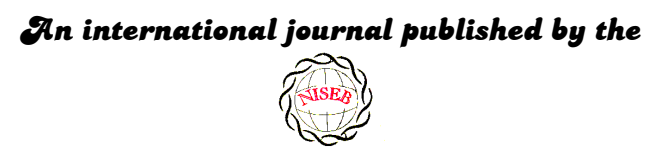

OVigerian Society for \&̊xperimental Siology

\title{
The effect of processing and preservation methods on the oxalate levels of some Nigerian leafy vegetables
}

\author{
Emmanuel O. OGBADOYI ${ }^{1 *}$, Hussaini A. MAKUN ${ }^{1}$, Rashidat O. BAMIGBADE ${ }^{1}$, \\ Abdurasheed O. OYEWALE ${ }^{1}$ and Johnson A. OLADIRAN ${ }^{2}$ \\ ${ }^{I}$ Department of Biochemistry, Federal University of Technology, Minna, Nigeria. \\ ${ }^{2}$ Department of Crop Production, Federal University of Technology, Minna, Nigeria.
}

Received 15 June 2006

MS/No BKM/2006/019, @ 2006 Nigerian Society for Experimental Biology. All rights reserved.

\begin{abstract}
Titrimetric analysis was used to estimate the level of oxalate in some Nigerian leafy vegetables treated in different ways in two sets of experiments. The treatments were boiling with retention of the water used for boiling, and freezing followed by boiling without retention of the water used for boiling. Results obtained showed that the former in which five different vegetables were used led to significant increases $(\mathrm{p}<0.05)$ in the oxalate content of the vegetable preparations. The exception was Vernonia amygdalina in which there was a significant decrease in the oxalate content after boiling. The latter in which three selected vegetables were used however led to significant decrease $(\mathrm{p}<0.05)$ in the level of oxalate of the vegetable preparation, a significant amount having been lost in the decanted water. Boiling and then discarding the water used for boiling vegetables provides a good means of reducing the oxalate content of leafy vegetables and consequently the associated food safety problems.
\end{abstract}

Keywords: Oxalate, Toxicosis, Leafy vegetables, Antinuitrients

*Author to whom correspondence should be addressed.

E-mail: eogbadoyi@yahoo.com , Tel: 066222304 


\section{INTRODUCTION}

Vegetables, especially leafy vegetables are an important source of vitamins, minerals, fibre, and some essential amino acids ${ }^{1,2,3}$. Vegetables are also a good source of polyunsaturated fatty acids and it is believed that sufficient consumption of vegetables is a preventive measure against cardiovascular diseases ${ }^{4}$. Whiteny et $a l^{5}$ reported that vegetables when eaten in sufficient amount may be helpful in reducing the incidence of colon and stomach cancers.

Despite these advantages, vegetables unfortunately contain significant levels of antinutrients and toxic substances. These include alkaloids, phytate, cyanide, nitrates, and oxalate. These substances, which under normal conditions are localised to separate compartments, come in contact wit the nutrients during processing and/or digestion in the gastrointestinal tract ${ }^{6}$. When released from their compartments, many of these antinutrients such as phytate and oxalate form insoluble complexes with important mineral elements such as calcium, iron, magnesium, and zinc $\mathrm{z}^{1,2,5,7,8}$. This reduces the bioavailability of these mineral elements with the attendant health problems such as oxalemia ${ }^{1}$. Oxalate, which helps in the maintenance of ionic balance in plants ${ }^{2}$, is an end product of metabolism in plants. Apart from reducing the bioavailability of very important mineral elements, direct effect of oxalate toxicoses resulting in death of swine and cattle following consumption of amaranth $120-300 \mathrm{~kg}^{-1}$ dry matter has been reported ${ }^{9}$. For continued consumption of vegetables and derivation of the immense nutritional benefits they offer, especially to the low income group who cannot afford the more expensive alternative sources, ways and means have to be sought to eliminate or at least reduce significantly, the potential toxicological dangers of the constituent antinutrients and toxic substances. This could be by the manipulation of one of the following: the soil environment in which the plant is grown, time or season of planting and/or harvesting, type of species grown, and preservation and processing methods. To the best of our knowledge, most of the information available on
Nigerian leafy vegetables is on chemical and nutrient composition with a description of the potential dangers of constituent antinutrients and noxious substances. Therefore, our current knowledge of the practical means by which the levels of these substances could be reduced to within safe limits of $0-05 \%$ is grossly inadequate. Unfortunately, these substances are inevitably present in vegetables. This limits the importance of vegetables in nutrition, as the nutritional importance of any given food is a function of its nutrient and antinutrient composition $^{10}$. In recognition of the importance of food safety in public health, and as part of our efforts to find ways of reducing the levels of antinutrients in vegetables, the present study examined the effects of cooking and the interplay of processing and preservation methods on the oxalate levels of some selected leafy vegetables commonly consumed across Nigeria.

\section{MATERIALS AND METHODS}

\section{Vegetables}

Vegetables were bought in two sets at different times from Bosso and Mobil markets in Minna, Nigeria except for Vernonia amygdalina which was obtained fresh from a home garden. Fresh samples of Amaranthus hybridus (spinach), Telifaria occidentalis (fluted pumpkin - "ugu"), Corchorus olitorius (long fruited jute "Ewedu"), Hibiscus sabdariffa (Roselle) were purchased from Bosso Market in Minna for the first set of experiments while fresh samples of Amaranthus hybridus (spinach), Telifaria occidentalis (fluted pumpkin - "ugu"), and Corchorus olitorius (long fruited jute "Ewedu"), were purchased from Bosso market, Minna for the second set of experiments.

\section{Chemicals}

Unless otherwise stated, all chemicals used were obtained from $\mathrm{BDH}$ and sigma chemical companies, both of England and were all of analytical grade.

\section{Uncooked samples}

$10 \mathrm{~g}$ of each of the samples were accurately weighed, homogenized using mortar and pestle, transferred into clean beaker and $5 \mathrm{ml}$ distilled 
water added. The resulting solution was filtered using cheese cloth and $500 \mathrm{ml}$ of $1 \mathrm{M} \mathrm{H}_{2} \mathrm{SO}_{4}$ added to the filtrate and the filtrate used for soluble oxalate estimation.

\section{Cooked samples}

$10 \mathrm{~g}$ of each of the samples (except Vernonia amygdalina) were washed and chopped into tiny pieces with kitchen knife and added to $200 \mathrm{ml}$ of boiling distilled water in a beaker. This was allowed to cook for 5 minutes. The solution was allowed to cool, made up to $500 \mathrm{ml}$ with distilled water, filtered and $500 \mathrm{ml}$ of $1 \mathrm{M} \mathrm{H}_{2} \mathrm{SO}_{4}$ added to the filtrate which was then used for analysis. In the case of Vernonia amygdalina, 50g of the leaves were washed by mashing the leaves in between the hands under running tap water. $10 \mathrm{~g}$ of the washed leaves were then processed for oxalate determination.

\section{Oxalate determination}

Oxalate was determined using titrimetric method as described by Bassett et $a l^{11}$.

\section{RESULTS}

The results presented were obtained from two sets of study. Table 1 shows the results obtained from the first set of experiments. The values, which are each, an average of three determinations were obtained by examination of the effect of cooking (water used in cooking retained) on the level of oxalate in the selected vegetables.

Table 1: Oxalate levels of five Nigerian leafy vegetables as a function of cooking method. Mean Amount of oxalate

Vegetable

$(\%)$

\begin{tabular}{lll}
\hline & Unboiled & Boiled \\
Amaranthus hybridus & $0.19 \pm 0.02^{\mathrm{a}}$ & $0.64 \pm 0.02^{\mathrm{c}}$ \\
Telifaria occidentalis & $1.27 \pm 0.02^{\mathrm{e}}$ & $1.41 \pm 0.02^{\mathrm{f}}$ \\
Corchorus olitorius & $0.59 \pm 0.02^{\mathrm{c}}$ & $1.50 \pm 0.01^{\mathrm{g}}$ \\
Hibiscus subdariffa & $1.22 \pm 0.01^{\mathrm{e}}$ & $1.57 \pm 0.02^{\mathrm{g}}$ \\
Vernonia amydalina & $0.80 \pm 0.02^{\mathrm{d}}$ & $0.28 \pm 0.01^{\mathrm{b}}$ \\
\hline Data on the same row carrying different superscripts \\
differ significantly from each other $(p<0.05)$
\end{tabular}

Table 2 shows the results of the effect of slight modification in the cooking procedure (water used in cooking removed) and the combined effects of freezing and cooking on the oxalate levels of three selected vegetables obtained in the second set of experiments. The data obtained were statistically analyzed using One-Way ANOVA. Statgraphics statistical system (version 2.6) was used.

\section{DISCUSSION}

Our analysis of oxalate levels in selected leafy vegetables prepared in slightly two different ways showed that the level of oxalate in vegetables could be reduced considerably by manipulating the cooking method.

Table 2: Oxalate levels of selected leafy vegetables as a function of cooking method and the interplay of freezing and cooking method.

\begin{tabular}{|c|c|c|c|c|c|c|c|c|c|}
\hline \multirow[t]{3}{*}{ Vegetable } & \multicolumn{9}{|c|}{ Amount of oxalate $(\%)$} \\
\hline & \multicolumn{3}{|c|}{ Unfrozen } & \multicolumn{6}{|c|}{ Frozen } \\
\hline & Unboiled & Boiled & $\begin{array}{l}\text { Decanted } \\
\text { water }\end{array}$ & \multicolumn{3}{|c|}{2 Weeks } & \multicolumn{3}{|c|}{4 Weeks } \\
\hline & & & & Unboiled & Boiled & $\begin{array}{l}\text { Decanted } \\
\text { water }\end{array}$ & Unboiled & Boiled & $\begin{array}{l}\text { Decanted } \\
\text { water }\end{array}$ \\
\hline $\begin{array}{l}\text { Amaranthus } \\
\text { hybridus }\end{array}$ & $\begin{array}{l}0.22 \pm \\
0.00^{\mathrm{e}}\end{array}$ & $\begin{array}{l}0.17 \pm \\
0.01^{\mathrm{d}}\end{array}$ & $\begin{array}{l}0.08 \pm \\
0.01^{\mathrm{c}}\end{array}$ & $\begin{array}{l}0.15 \pm \\
0.00^{\mathrm{f}}\end{array}$ & $\begin{array}{l}0.07 \pm \\
0.01^{\mathrm{c}}\end{array}$ & $\begin{array}{l}0.08 \pm \\
0.02^{\mathrm{c}}\end{array}$ & $\begin{array}{l}0.07 \pm \\
0.01^{\mathrm{c}}\end{array}$ & $\begin{array}{l}0.02 \pm \\
0.00^{\mathrm{ab}}\end{array}$ & $\begin{array}{c}0.04 \pm \\
0.00^{\mathrm{a}}\end{array}$ \\
\hline $\begin{array}{l}\text { Telifaria } \\
\text { occidentalis }\end{array}$ & $\begin{array}{l}0.28 \pm \\
0.01^{\mathrm{d}}\end{array}$ & $\begin{array}{l}0.17 \pm \\
0.01^{\mathrm{b}}\end{array}$ & $\begin{array}{l}0.09 \pm \\
0.00^{\mathrm{ab}}\end{array}$ & $\begin{array}{l}0.25 \pm \\
0.00^{\mathrm{e}} \\
\end{array}$ & $\begin{array}{l}0.12 \pm \\
0.01^{\mathrm{c}}\end{array}$ & $\begin{array}{l}0.12 \pm \\
0.01^{\mathrm{c}}\end{array}$ & $\begin{array}{l}0.17 \pm \\
0.00^{\mathrm{b}}\end{array}$ & $\begin{array}{l}0.03 \pm \\
0.00^{\mathrm{a}}\end{array}$ & $\begin{array}{l}0.12 \pm \\
0.00^{\mathrm{c}}\end{array}$ \\
\hline $\begin{array}{l}\text { Corchorus } \\
\text { olitorius }\end{array}$ & $\begin{array}{l}0.03 \pm \\
0.01^{\mathrm{d}}\end{array}$ & $\begin{array}{l}0.02 \pm \\
0.00^{f}\end{array}$ & $\begin{array}{l}0.00 \pm \\
0.00^{\mathrm{c}}\end{array}$ & $\begin{array}{l}0.02 \pm \\
0.00^{\mathrm{ab}}\end{array}$ & $\begin{array}{l}0.02 \pm \\
0.00^{\mathrm{ab}}\end{array}$ & $\begin{array}{l}0.01 \pm \\
0.01^{\mathrm{a}}\end{array}$ & $\begin{array}{l}0.02 \pm \\
0.00^{\mathrm{ab}}\end{array}$ & $\begin{array}{l}0.01 \pm \\
0.00^{\mathrm{a}}\end{array}$ & $\begin{array}{l}0.01 \pm \\
0.00^{\mathrm{a}}\end{array}$ \\
\hline
\end{tabular}

Data on the same row carrying different superscripts differ significantly from each other $(p<0.05)$ 
It can be seen from Table 1 that in all but one, the oxalate content of the vegetables increased on cooking without prior boiling and then discarding the water. This could be attributable to a leaching effect of cooking process, releasing more oxalate from the leaves. The deviation from this general trend shown by Vernonia amygdalina stresses two important points. Firstly, it shows that processing method influences the level of oxalate in the final vegetable preparation. Secondly it gives credence to the belief that discarding the water used in boiling prior to cooking vegetables reduces the level of oxalate considerably in the final preparation ${ }^{8}$. Unlike the other five vegetables, Vernonia amygdalina leaves were washed several times and the water discarded in order to remove or reduce the bitterness in the leaves. This processing step, we believe, accounts for the observed $65 \%$ reduction in the oxalate level of this vegetable after cooking. In the other vegetables where there was no such extensive washing, there was increase rather than decrease in the level of oxalate. It is therefore possible that if the water used in boiling the vegetables had been discarded, the oxalate content of the vegetables might have been significantly reduced. The problem with discarding the water used for boiling however is the fear of losing water soluble vitamins especially the B vitamins ${ }^{12}$. In order to confirm some of our observations in the first part of this study, three vegetables were selected from the five used in the first set of experiments and the processing method was slightly modified by removing the water used in cooking. The vegetables were also frozen over a 4-week period and the uncooked and cooked samples were periodically analysed to determine the combined effects of freezing and cooking on the oxalate content of the three selected vegetables.

Analysis of the water used in cooking showed that considerable amount of oxalate was lost in the decanted water (Table 2). Cleveland and Soleri $^{8}$ reported that boiling or steaming of vegetables and then rinsing them and discarding the water reduced their oxalate content. Our findings are in support of this earlier observation A more interesting result is the considerable reducing effect of the interplay of freezing and boiling on the level of oxalate in the final vegetable preparation (Table 2). It is interesting because freezing is a relatively very cheap technology and requires no skill. Freezing alone (for 4 weeks) reduces the level of oxalate by as much as $73.5 \%$ in Amaranthus. Two weeks of freezing produced a $33.3 \%$ increase in the oxalate level of Corchorus olitorius as opposed to the $7.66 \%$ and $35.16 \%$ decrease in Telifaria occidentalis and Amaranthus hybridus respectively. The effect of freezing therefore may very much depend on the type of vegetable. Oxalate is a metabolic product in plants and the reducing effect of freezing is probably as a result of the general stoppage of all metabolic reactions at freezing temperatures. For instance it is known that the activity of the enzyme ascorbase, which converts ascorbic acid to oxalate, increases with storage of vegetables and fruits especially under warm conditions ${ }^{8}$.

At freezing conditions, the activities of all enzymes are stopped and therefore production and accumulation of oxalate is prevented. This seems unlikely as the time between freezings and analyzing the fresh samples is not much to allow such a difference. Freezing also by some mechanisms unknown to us appears to facilitate the release of oxalate into the cooking water. However it is known that freezing of tissues at high moisture content results in the formation of ice crystals within the cells. The sharp edges of the crystals so formed are capable of lacerating the cell membranes resulting in cell leakage. It is therefore possible that freezing of the fresh leaves might have led to cell leakage leading to considerable loss of oxalate from its cellular compartment into the water used in boiling the vegetables. If this is true, then there is the danger of losing vitamins and minerals as well. Freezing however has been reported to minimize losses of vitamins and minerals ${ }^{13}$.

Although the underlying mechanisms for some of these observations are not yet understood it is believed that freezing and controlled boiling of vegetables and then throwing away the water used for boiling before using leafy vegetables in meals will considerably reduce the oxalate content of vegetables. However in doing this, it is important to ensure that water soluble 
vitamins and minerals are not compromised. With genetic factors rather than ecological factors being the major determinant of the oxalate content of leafy vegetables ${ }^{1,8}$ a good choice of species grown, in combination with controlled preservation and processing methods may eliminate completely the potential dangers of oxalate toxicoses and any antinutrient effect.

\section{REFERENCES}

1. Oyenuga, V. A. and Fetuga, B. L. (1975) Dietary importance of fruits and vegetables. First National Seminar on Fruits and Vegetables. Ibadan. Pp 122-129.

2. Grubben, G.J.H. (1976) The cultivation of Amaranth as a tropical leaf vegetable. Communication 67, Department of Agricultural Research, Royal Tropical Institute, Amsterdam pp 11-41.

3. Alfred, P. and Patrick, P. (1985) Integrated Food Science and Technology for the Tropics Macmillan Publishers, London. Pp 293-303.

4. Murcia, M.A. Vera, A., Garcia-Carmona, F. (1992) Effect of processing methods on spinach: proximate composition in fatty acids and soluble protein. Journal of Science, Food and Agriculture 59:473-476.

5. Whitney, E. N. and Hamilton, E. M. N. (1990) Understanding Nutrition. West Publishing Company, St Paul, USA. pp 43

6. Kaushaiya, E. J., Cannon, H. L. and Underwood, H. W. (1988) Toxicants Occurring Naturally in Foods. National
Academy of Sciences, Washington D.C. pp 43-87.

7. Guthrie, H. A. (1990) Introductory Nutrition. The C.V. Mosby Company Pp 1920.

8. Cleveland, D. A. and Soleri, D. (1991) An ecological, nutritional and social approach to small scale house holds food production. Food from Dry land Gardens, Centre for People, Food, and Environment (CPFE), USA. Pp 26-29.

9. James, L.F. (1972) Oxalate toxicoses. Clinical Toxicology 5:231-243.

10. Prohp, T. P., Ihimire, I. G., Madusha, A. O., Okpala, H. O., Erebor, J. O., Oyinbo, C. A. (2006) Some antinutritional and mineral contents of extra-cotyledonous deposit of Pride of Barbados (Caesalpina pulcherima). Pakistan Journal of Nutrition 5: 114-116

11. Bassett, J., Denney, R. C. William, G. H. and Mendham, J. (1978) Vogel's Textbook of Quantitative Inorganic Analysis, Longman Group Limited, New York. pp 352

12. Martin, F.M. and Ruberte, R.M (1975) Edible Leaves of the Tropics. Antillian College Press, Puerto Rico pp 5-15.

13. Baker, A.A. and Gawish, R. A. (1997) Trials to reduce nitrate and oxalate content in some leafy vegetables. 2. Interactive effects of the manipulating of the soil nutrient supply, different blanching media and preservation methods followed by cooking process. Journal of Science, Food and Agriculture 42: 169-178. 